\title{
LYRICAL INTERPRETATION OF “I” IN THE POETRY OF ANBAR OTIN, DILSHODI BARNO AND SAMAR BONU
}

\section{Oybek Barziev}

Doctor Of Philosophy In Philological Sciences (Phd) Teacher, Department Of "Uzbek Language And Literature", Fergana State University, Uzbekistan

\section{ABSTRACT}

The article interprets the lyrical "I" used by Anbar otin, Dilshodi Barno, Samar Bonu in the genres of ghazal, muhammas, mustahzod. In the comprehensive coverage of the fate of poets and the discovery of the problems of their time, the auto-psychological lyrical "I" method is included in the scope of analysis.

KEYWORDS: - Lyrical protagonist, auto-psychological lyrical "I", the work of the heart, the motives of emigration, bloodshed, fullness.

\section{INTRODUCTION}

Anbar Otin, Dilshodi Barno and Samar Bonular have a special place in the Uzbek literature of the late 19th and early 20th centuries. At the same time, their works are influenced by famous poets of the Fergana Valley, such as Jahan Otin Uvaysi and Mohlaroyim Nodira. In particular, the fate of these three poets is rich in tragic and topical issues; they were expressed in the ghazals, muhammas, and mustazzads of the ancient genres of classical literature.

It is known that in the last moments of Anbar Otin's life, his leg was injured and he lay down. The reason is that he speaks the "truth" at a meeting of contemporary women, suffers because of them, and is crippled for life, according to literary sources. The author Sabir Abdulla's novel "Mavlono Mukimiy" tells about his life from the speech of the poet's wife Zahidkhoja. The following information about Muqimi in the novel is noteworthy:

“... he is paralyzed, he writes poetry and reads a lot of books. He begged me for a long time, "If you go to the poet Muqimi and tell him my request, if they come one step further, get acquainted with my condition, get acquainted with my poems, I do not want to lie behind the curtain and talk to him!" I wouldn't listen" [1, p. 269].

There are many days when the fate of the poet Dilshodi Barno is written in the chapter on the fate of Anbar Otin, who suffered from ill health. It is known in the history of literature that Dilshodi Barno was separated from his parents at the age 
CURRENT RESEARCH JOURNAL OF PHILOLOGICAL SCIENCES 2(6): 61-66,

May 2021 DOI: https://doi.org/10.37547/philological-crjps-02-06-13

ISSN 2767-3758

(C)2021 Master Journals

\section{Crossref do) 8 Google}

Accepted23thJune, 2021 \& Published 28thJune, 2021

of fourteen, grew up in an orphanage, and was brought to Kokand by Umarkhan from Uratepa, where he was born and raised at the age of seventeen. This was stated by the literary critic M., who studied the poet's creative path. Kadyrova: "Kokand khan Umarkhan conquered Uratepa in 1816-17 and brought many captives to Kokand. Among them was 17-year-old Dilshod" [2, p. 3].

\section{T HE MAIN FINDINGS AND RESULTS}

Samar Bonu is one of the poets of the Fergana Valley who openly sang her "I" in her lyrical works on social issues. The fate of the poet, who was the cousin of the poet Huvaydo in the history of literature and suffered by his relatives because of his "work of the heart", is also tragic. Literary critic T. Jalolov, who conducted research on the life and work of Samar Bonu: "Bonu fled to Mingtepa, to his Majnun Sharifjon. The father, who instigated his daughter's courage, whitewashed Bonu, deprived her of her inheritance [3, p. 282], and the whole generation turned away from her, he said, "referring to the From the 19th century onwards, women's voices began to sound louder in Uzbek literature" [3, p. 282].

In the works of these three poets, the ghazal, the muhammas, and the mustahzads have a strong tradition of attaching their personal life and social content to it. This, in turn, created a tradition of poetic series in lyrical works written on a social theme. The role of the lyrical "I" in such poems, which describe the personality and lifestyle of the poets, is important, and they are accompanied by social pathos. At this point, it is necessary to distinguish between the concepts of lyrical hero and lyrical "I", which are actively used in poetry. Literary dictionaries say, "Just as an image is broader and more multifaceted than a prototype, so a lyrical protagonist is broader than a poet's personality, his autobiography" [4, p. 165]. It is on the basis of this definition that the auto--psychological method of the lyrical "I" prevailed in the ghazals, muhammas, and mustazzads of the poets involved in the analysis. About this type of lyrical "I" Professor D.Kuronov: "Auto-psychological lyrics are poems in which the lyrical protagonist and the poet's personality seem to coincide, or rather, the two are closely related. In such poems, the poet speaks in the language of "I", addresses more to his heart, and expresses himself [5, p. 272], his heart. At the same time, they cover the problems of the time: injustice, bloodshed, betrayal of rights, as well as a number of atrocities in the Fergana Valley. In the lyrical works of the poets, the tradition and commonality of the poetic series can be seen in their skills of using words such as "I", "myself" or in the effective use of possessive 1st person suffixes. For example, Anbar Otin's poem in the mustahzod genre was written in the spirit of hasbi hal. In it, the poet calls herself "oppressed" and is proud to have been given the title of woman. The autopsychological lyrical image of "I" is evident in the fact that he writes that his leg is crippled:

Kelgusi yorug'dunyog'a borishchun oyog'im, hozircha erur majruh,

Dod aylamagim mumkin emas, bu badanimda qaydi Kamanim bor. [6, p. 68]

My foot is crippled for the time being to go to the next bright world,

I can't scream, I have a bow in my body.

The lyrical "I" in the poet's mustah is not overly depressing. While the word "thorn" used in Mustahzod refers to the sinking of society into a quagmire of decline, the word "horse tied to a sign of hope" refers to a lyrical "I" looking to the future with a bright eye.

Or the ghazal "Amir" by Dilshodi Barno is autobiographical and is dedicated to the poet Amir Umarkhan. In his part of the matla, Amir is 
CURRENT RESEARCH JOURNAL OF PHILOLOGICAL SCIENCES 2(6): 61-66,

May 2021 DOI: https://doi.org/10.37547/philological-crjps-02-06-13

ISSN 2767-3758

(C)2021 Master Journals

\section{Crossref do) 8 Google}

Accepted23thJune, 2021 \& Published 28thJune, 2021

described as a king to the land of poetry, a refuge on the path of creation. He is called the one who controls the verses of the people of Fergana, who feed them with his eyes, that is, who supports the poets materially and spiritually:

She'riyat kishvarig'a shoh Amir,

Hamqalam do'stlarig'a panoh Amir.

King Amir to the country of poetry,

Shelter to all my friends Amir.

The poet's six-verse muhammad is dedicated to the description of Fergana, in which the lyrical "I" is Dilshodi Barno himself. In the first verse of Muhammas, there is a peculiar description, and the poet becomes the guardian of his country, saying that he slept with Fergana in the dark of night and shot a bullet in the chest. In the second verse, the name Kokand is mentioned, and the poet says that he grew up in her bosom and that he wants to make the country laugh in the end. The auto-psychological method of the lyrical "I" in Muhammas is explained in the following verse by the fact that oppression is temporary:

Ey jonajonim, hech bo'lma diqqat,

$\mathrm{Bu}$ jabru zulmat albat muvaqqat.

Ketar boshingdin barcha mashaqqat,

Zamona qilg'ay oxir bir shafqat,

Ko'nglimda yo'qdir zarra gumonim [6, p. 76].

Be careful, my dear,

This oppressive darkness is certainly temporary.

All the hard work,

The end of time is a mercy,

I have no doubt in my mind.

The auto-psychological method of lyrical "I" is also predominant in the poems of Samar Bonu, originally from the village of Chimyon, Fergana region. In the ghazals written by the poet, the vivid examples of hasbi statehood are especially strongly expressed in the ghazals "Bonu gharib" and "Yor jabr etti". They skillfully express the depressed mood of the lyrical "I" and the thirst for separation. The literary critic T. Jalolov writes that the reason for the young poet's life as a flower was the early death, that is, the death of his wife Sharifjon, his father Siroji: "Ten months later, Sharifjon's assassins killed him. Bonu was widowed at the age of nineteen with her baby Zahriddin in her arms. He is literally lonely, lonely, and a stranger" [3, p. 284]. In the poem "Yor jabr etti" the poet describes his state of mind as

G'orat etti mulki tanni shohi oshiqlar kelib,

Bir qushe uchdi qo'limdin ko'k sari parvozlab [7, p. 113].

Samar Bonu became a true love singer after a heavy loss. In his poems, the auto-psychological method of "I" is portrayed as a hero in distress due to emigration. In this regard, "I will never forget you" is ghazal:

Jafou jabri ko'p solding, ayo e rahmi yo'q zolim,

Yubormading xayoling itlarini ko'rg'ani hargiz [7, pp. 118-119].

You have suffered a lot; you are a cruel tyrant,

You never saw the dogs of your imagination.

Or in the poem "Buzar Mahsharni Bonu" the lyrical "I" warns of a broken heart:

Falak charxing buzulsin, men g'arib boshida cho'rulding,

Menga har vajha zulm etting, Netoy jonimmudur fo'lod?

Hama el orzusig'a etib bisyor shod o'ldi,

Meni vayrona ko'nglum bu jahonda bo'lmadi obod...

Let the celestial wheel be broken, I roared in a strange head,

You have wronged me in every way. 
CURRENT RESEARCH JOURNAL OF PHILOLOGICAL SCIENCES 2(6): 61-66,

May 2021 DOI: https://doi.org/10.37547/philological-crjps-02-06-13

ISSN 2767-3758

(C)2021 Master Journals

Crossref do: 81 Google

Accepted23thJune, 2021 \& Published 28thJune, 2021

Hama died in a state of ecstasy,

My broken heart was not in this world, prosperity...

A series of ghazals with motives of "destruction of the heart" in their poems occupies a leading place in the work of these poets.

Anbar Otin's poem "Vasiyat - Will” describes the poet's words before his death. Saying that they will not weep after her death, the poetess, who welcomes her death like a wedding, predicts the next life path of her daughter and son:

Man o'lsam, ey birodarlar, qizimni kuyovga bering!

Sudxo'ru boy, zolimlarg'a zid birovga bering.

Bechora qizim murabbiysiz qolg'anda ango,

G'amxo'r o'lguvchi bir aqlik suyyovga bering [6, p. 20].

If I die, brothers, give my daughter to the groom!

Give it to someone who is rich and oppressive.

When my poor daughter was left without a coach,

Give it to a caring dying savage.

From the content of the will, the state of the mother, who was disappointed in her time, manifests itself as a lyrical "I", and she thinks about the fate of her child at the last moment.

Or Dilshodi Barno's lyrical "I" in the radical poem "Ustina" appears as "the guardian of the country." In the third verse of the ghazal, he is the guardian of the homeland, and his intention to protect it is revealed. The poet, who intends to put a speck on the finger of Fergana if there is a needle in a haystack, puts forward a social content - the idea of protecting his country from foreigners:

Ignadek dog'o'rnasa bu kishvari Farg'onag'a, Cho'g'bosg'um dog'solg'on hama barmoq ustina
[6, p. 61].

If a needle-like spot appears, this country will go to Fergana,

Charcoal stains are on the fingertips.

The lyrical "I" is proud of the fact that the gazelle is playing in a strange verse, and regrets that oppression and violence are playing on the heads of the mourners:

Bu Vatan dardini aytib, soz cholg'onim uchun,

Zulm o'ynar kecha kunduz barcha mushtoq ustina.

This is my homeland, telling the pain of the word, Oppression plays on all the nightmares day and night.

Or the mood of the lyrical "I" was reflected in the high-pitched ghazal "Aylamas". In this muhammas, too, the poet shares her feelings and dreams:

Sho'r baxtimga azizim yuzni pinhon ayladi,

Va'da qildiyu, visolin bag'rimni qon ayladi,

Yig'latib ishqida ko'zni abri nayson ayladi,

Oxiri bu shum raqibim qasdi bir jon ayladi,

Hech ma'shuq oshiqini bo'yla sarson aylamas [6, p. 77].

To my salty happiness my dear hid his face,

Promising, meeting turned my liver into blood,

Crying made his eyes water at work,

In the end, my opponent was killed,

No lover wanders around in love.

The tradition of linking personal life with social content in his poems is a characteristic feature of the poet's work. His ghazal with the radicle "Bitter" can be a proof of our opinion. The poet's experiences in the ghazal, which made effective use of the art of contrast and parable (example), fully express their purpose in a foreign verse and 
CURRENT RESEARCH JOURNAL OF PHILOLOGICAL SCIENCES 2(6): 61-66,

May 2021 DOI: https://doi.org/10.37547/philological-crjps-02-06-13

ISSN 2767-3758

(C)2021 Master Journals

Crossref do) 81 Google

Accepted23thJune, 2021 \& Published 28thJune, 2021

express the fact that he suffered as a result:

Vasl hangomini kutdum, keldi bu hangom talx,

Navro'zim subhini kutdum, lek keldi shom talx.

Bir yo'li yuzimga boqmoq o'rniga ul bevafo,

Tarsaki urdi yuzimga, bu dedi in'om talx [6, p. 31].

I've been waiting for you; it's time to talk,

I waited for the morning of Navruz, and the evening came.

Instead of looking at my face one way, he is unfaithful,

The applause hit me in the face, said the bitter gift.

The lyrical "I", who waits for the dawn but welcomes the bitter evening, expresses the injustices and bloodshed in society with a "slap in the face".

In the poem "Nobody is like me" by Samar Bonu, the poet's feelings are shared with Anbar Otin's ghazal, which begins with "Don't sleep like me, wake up ...". There is a method of comparison in both ghazals, while Samar bonu connects his thoughts with his way of life, his way of life, while Anbar devotes his views to awakening the women of Fergana from their slumber.

Samar Bonu begins his ghazal with the fact that he is tired of marriage and saddened:

Hech kishi mendek jahonni ayshidin bezor emas, Intizorlik tortmoq uchun doimo tayyor emas.

Ishqi savdosi ko'ngulda, o'zga g'am yo'q dilda hech,

Hech kishi bag'ri meningdek doimo afgor emas [7, p.120].

No one is as tired of the world as I am.

The wait isn't always ready to pull off.
Love trade in the heart, no other grief in the heart,

No one is always as afghan as I am.

In Anbar's ghazal matla, there is a special call for women:

Mendek yotma, uyg'ongil, ey zanoni Farg'ona!

Erlardek bel bog'la emdi bo'lib mardona.

Mani boshimdadursiz, do'stlik qilursiz,

G'azallarimni tinglab, xuddi parvona [6, p. 17].

Do not lie down like me; wake up, 0 woman of Fergana!

He was as brave as a man.

You are in my head, you make friends,

Listening to my poems is like a propeller.

In the next verses of Samar Bonu's ghazal, the lyrical "I" speech is sharpened, which indicates that it was ultimately "blood of the liver":

Dahr dog'idin yurogim tah-batah qon bog'ladi,

Hech kishi mendek yurogi dasta-dasta xor emas.

Orzuyi vasli birla ro'zu shab bekor o'lub,

G'ussa birla qon yutub bag'ri aning zangor emas.

My heart was bleeding from the stain of Dahr,

No one is as humiliated as I am.

He died on the night of Ramadan,

Grief swallowed blood and his liver was not blue.

When the time comes, this unique analogy, which belongs to the pen of women poets, is found in the poet Uvaysi and Nodirabegim, it is a tradition of the poetic series in the chapter on the use of words.

The description of the liver's blood in the barn horse is interchangeable with the phrase "filling the pile":

Bu dard mandin yiroq bo'lishni istamas, 
CURRENT RESEARCH JOURNAL OF PHILOLOGICAL SCIENCES 2(6): 61-66,

May 2021 DOI: https://doi.org/10.37547/philological-crjps-02-06-13

ISSN 2767-3758

(C)2021 Master Journals

Crossref dof 81 Google

Accepted23thJune, 2021 \& Published 28thJune, 2021

O’xshaydur oxiri to'ladur paymona.

Paymonam qay kuni to'lsa agar, do'stlarim,

Xalq ichinda o'qug'aysiz g'azal, afsona.

This pain does not want to be far from me,

It looks like a sack that encloses with a drawstring.

If my day is full, my friends,

A ghazal, a legend, unreadable among the people.

\section{Conclusion}

Thus, the auto-psychological method of "I" used in the works of these poets of Uzbek literature during the period of national awakening helped to illuminate their way of life. The poets appealed to the realistic colors of their destiny and applied social content to them. At the same time, creatively influenced by each other on the issue of word-speaking skills, they have preserved the examples of poetic series in their time as a tradition.

\section{REFERENCES}

1. Sobir Abdulla. (1978) The third roof. Mevlana Mukimiy. Art plates. - Tashkent: Gafur Gulom Publishing House of Literature and Art. - p. 269.

2. Dilshod. Selected works. Prepared by: Kadyrova M. - Tashkent: Gafur Gulom Publishing House of Literature and Art. 1972. - p. 3.

3. Jalolov T. (1980) Uzbek poets. - Tashkent: Gafur Gulam Publishing House of Literature and Art. - pp. 282, 284.

4. Hotamov N., Sarimsoqov B. (1979) RussianUzbek Glossary of Literary Terms. Tashkent: Teacher. - p. 165.

5. Kuronov D.H. (2019) Fundamentals of literary theory. - Tashkent: NOSHIR. - p.
272.

6. Anbar otin. Poems. Risola. Collector and foreword author: Husainova F. - Tashkent: Gafur Gulam Publishing House of Literature and Art. 1970. - pp. 20, 68, 76.

7. The seven lights of the East. Gazelles. Prepared by: Akbarkhojaev T. - Tashkent: Abdulla Kodiri National Heritage Publishing House, 1999. - pp. 113, 118-119, 120. 